\title{
電気めっきの化学
}

千葉 国雄*

\section{Chemistry of Electroplating}

Kunio CHIBA*

*メルテックス株式会社研究部（テ 330 埼玉県大宮市吉野町 2-1)

* Research \& Development Dept., Meltex Inc. (2-1 Yoshino-cho, Ōmiya-shi, Saitama 330)

\section{1.はじめに}

プリント配線板に用いられるめつき技術には，無 電解めっき（化学めっき）と電気めっきがある。無 電解めっきは，還元剤の還元力によって金属を析出 させるのに対し，電気めっきは外部の電源から一定 の電圧を加えることによって金属を析出させる方法 である。

無電解めっきは，スルーホールめっき製造工程に おいて, ドリリング後, 露出した基材表面（非電導 性）に電導性皮膜を形成する目的で使用され，還元 剤としてホルマリンを使用した無電解銅めっきが用 いられている。最近では，ホルマリンの発癌性がク ローズアップされ，グリオキシル酸1や $\mathrm{DMAB}^{2) な ~}$ どホルマリンを使用しない無電解銅めっきも発表さ れている。

電気めっきは, 無電解銅めっきによってスルー ホール内に銅の電導性皮膜を形成した後，電導性の 良い銅回路形成のため, 通常ピロリン酸銅めっきや 硫酸銅めっきが用いられている。また，電気銅めっ きの後に使用されるはんだめっきは，現在ではアル カリエッチング夜の金属レジストとしての目的で使 用される場合が多い。

プリント配線板の製造方法には,大別するとサブ トラクティブ法（エッチドホイル法）とフルアディ ティブ法がある。現在では, 銅張積層板を用いて電 気銅めっきにより所定の膜厚を確保した後，エッチ ングによって回路形成するサブトラクティブ法が主 流である。この製造工程の中で，めっき技術は確実
な導通信頼性を得るためにきわめて重要な工程であ る。

サブトラクティブ法は, 複雑な処理工程を必要と するが，量産性に優れ，製品の信頼性は非常に高い。 現在，ピン間 3 本以上の微細回路の製造が可能な銅 スルーホールめっき基板が圧倒的に多く生産されて いる。

銅スルーホールめつき基板の製造法には，はんだ はく離法, テンティング法, 穴埋め法などがあるが, はんだはく離法が最も微細回路の形成に有利であ り，歩留まりも高い。

本稿では, 現在サブトラクティブ法の製造に使用 されている電気めっきのうち, 硫酸銅めっきとはん だめっきの概要について述べる。

\section{2. 電気銅めつき}

\section{1 スローイングパワー（均一龟着性）}

一般に，マクロな表面のめっき分布を均一化させ る能力をスローイングパワーといい，ミクロな凹凹 のめっき分布の場合をレベリングという。

プリント配線板用の電気銅めっきは，スルーホー ル内を均一な膜厚にめっきするためのスローイング パワーが良好で, 析出皮膜の物性が優れていること が要求される。これらの要求に対し, 古くからピロ リン酸銅めっきが用いられてきた。

しかしながら，ピロリン酸銅めっきは，めっき浴 管理の難しさやオルソリン酸の蓄積による定期的な 浴更新, 廃水処理上の問題, はく離に溶剤（トリク レン等）を使用しない水溶性レジストが使用できな 
表 1 . 硫酸銅めつきの浴組成

\begin{tabular}{c|c|c|c}
\hline & 低電流密度作業用 & 中電流密度作業用 & 高電流密度作業用 \\
\hline 電流密度 $\left(\mathrm{A} / \mathrm{dm}^{2}\right)$ & $1.0(0.5 \sim 2)$ & $3(2 \sim 5)$ & $8(5 \sim 10)$ \\
\hline 硫酸銅 $(\mathrm{g} / \ell)$ & $50(30 \sim 60)$ & $75(60 \sim 90)$ & $120(100 \sim 120)$ \\
\hline 硫酸 $(\mathrm{g} / \ell)$ & $200(190 \sim 250)$ & $190(165 \sim 210)$ & $190(165 \sim 210)$ \\
\hline 塩素 $(\mathrm{mg} / \ell)$ & $40(30 \sim 50)$ & $40(30 \sim 50)$ & $40(30 \sim 50)$ \\
\hline 添加剤 & 若干 & 若干 & 若干 \\
\hline
\end{tabular}

いなどの理由により，ハイスロー硫酸銅めっきが主 流となってきている。

ピロリン酸銅めっき浴のスローイングパワーが優 れている理由は, めっき液中の銅イオンが錯化され ているので, 電析が高い過電圧のもとで行われるた めである。一方，硫酸銅めっきは，錯化物を使用し ない単純塩浴であるため, 過電圧が小さい。表 1 に, 硫酸銅めっきの浴組成を示した。

めっき浴には, めっき析出物の特性を向上させる ために, 微量の添加剤が添加されている。硫酸銅めっ きの添加剤は，主としてブライトナ，キャリア，レ ベラの 3 成分からなっている。この中で，キャリア は抑制阂（サプレッサ）とも呼ばれ，カソード表面 に吸着し，銅の析出を抑制する。この吸着によって 生じた過電圧により，基板表面とスルーホール内を 均一に分極し，スローイングパワーを向上させるこ とができる。

また, 過電圧と電流密度の関係は, 次式で表され

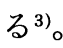

過電圧 $\eta=\mathrm{kRT} / \mathrm{FJ}(\mathrm{V})$

\section{ここで, $\mathrm{k}$ : 電導度}

$\mathrm{R}$ : 気体定数

$\mathrm{T} ：$ 絶対温度

$\mathrm{F} ：$ ファラデー定数

$\mathrm{J}$ : 電流密度

すなわち電導度が高く, 電流密度が低いほど大き な過電圧が得られるので, より良好なスローイング パワーが得られることになる。

硫酸銅めっきを使用し，高アスペクト比の基板を めっきする場合，良好なスローイングパワーを得る ためには, 硫酸濃度を高くして浴液の電導度を高め, 低電流密度にてめっきされている。

最近では，アスペクト比（板厚／穴径）の高い基
板へのめつきが増加しているため，良好なスローイ ングパワーを得ることが難しくなってきている。そ の理由は，アスペクト比が高くなるにつれて微小 ホール内での電位低下が起こるためである。ホール 内の電位低下 $\mathrm{E}_{\mathrm{ir}}$ と穴径, 板厚との関係は, 次式で表 される4)。

$$
\begin{aligned}
& \mathrm{E}_{\mathrm{ir}}=\mathrm{JL}^{2} / 2 \mathrm{kd}=\mathrm{K} \cdot \mathrm{L}^{2} / \mathrm{d}(\mathrm{V}) \\
& \text { ここで, } \mathrm{J}: \text { 電流密度 } \\
& \mathrm{L}: \text { 板厚 } \\
& \mathrm{k}: \text { 電導度 } \\
& \mathrm{d}: \text { 穴径 } \\
& \mathrm{K}: \text { 定数 }
\end{aligned}
$$

電位低下は， $\mathrm{L}^{2} / \mathrm{d}$ に関係し，同じアスペクト比の 基板へのめっきでも，板厚が厚いほうがスローイン グパワーが得られにくいことになる。

\section{2 皮膜の物性}

電気銅めっきの皮膜物性（抗張力，延性，硬度， 内部応力）は，スルーホールめっきの接続信頼性に 最も影響する。特に延性は，添加剤の分解生成物の 蓄積, 前処理工程からの薬剤の混入，めっきレジス トからの成分の溶出などによる有機污染物の皮膜へ の共析によって，低下する傾向がある。表 2 にピロ

\begin{tabular}{|c|c|c|}
\hline & ピロリン酸銅めっき & 硫酸銅めっき \\
\hline 抗 張 力 & $50 \sim 55 \mathrm{~kg} / \mathrm{mm}^{2}$ & $50 \sim 55 \mathrm{~kg} / \mathrm{mm}^{2}$ \\
\hline 延 性 & $4 \sim 10 \%$ & $17 \sim 25 \%$ \\
\hline 硬度 & $190 \sim 200 \mathrm{Hv}$ & $110 \sim 120 \mathrm{Hv}$ \\
\hline 結晶構造 & 層状 (無添加) & 柱状 (無添加) \\
\hline
\end{tabular}
リン酸銅めっき浴と硫酸銅めっき浴の物性值の比較 を示した。ピロリン酸銅めっきは, 抗張力および硬 度が高く, 硫酸銅めっきは延性が高いのが特徵であ る。

表 2 .ピロリン酸銅めつきと硫酸銅めつきの物性值の比較 


\section{3 添加凮の作用}

硫酸銅めっき液は, 硫酸銅, 硫酸, 微量の塩素イ オン, 有機添加剤からなっている。現在市販されて いる硫酸銅めっき浴の添加剤成分は, 大別するとブ ライトナ，キャリア，レべラからなっている。

ブライトナは, 光沢の付与, 析出粒子の緻密化, 展延性の付与, 内部応力の減少などの作用を有し, 析出を促進させる効果がある。ブライトナとしては, SAS（スルホニウム・アルカン・スルホネート）系 と, PES（ポリエーテル・サルファイド）系の化合 物が用いられている。

キャリアは，めっきの光沢範囲を広げ，良好な耐 熱試験結果を与える。特に, めっきの抑制剤として 作用する。一般に, 高分子界面活性剤が用いられて いる。

レベラは，低電流部の光沢改善および凹凸のある ホール内壁面を平滑にするためのレベリング剤であ る。添加剤は，これら 3 成分の良好なバランスによ り効果を発揮する。

\section{4 添加凮の定量方法}

電気銅めっきの添加剤の管理には，古くからハル セルテストが使用されてきた。ハルセルテストは, めつき液の状態を把握する最も簡便で迅速な方法で ある。しかしながら, 高多層, 高アスペクト比の基 板をめっきする場合は, より厳密な添加剤濃度管理 が必要となる。

最近では, CVS(サイクリック・ボルタンメトリッ ク・ストリッピング）法による添加剤の専用分析機 器が普及しつつある。

CVS 法は, 不活性回転円板電極 (Pt 電極) を2500 $\mathrm{rpm}$ の回転速度で回転させ， $-0.225 \sim 0.575 \mathrm{~V}$ (銀／ 塩化銀電極）の掃引領域を $100 \mathrm{mV} / \mathrm{sec}$.の掃引速度 で繰り返し変化させる。そのとき得られるはく離 ピークを測定することにより，めっき液中の添加剤 濃度を求めることができる。この方法によって,めっ き液中のブライトナ（標準添加法）とキャリア濃度 （希釈滴定法）を定量することができ, 添加剤の厳 密な管理が可能となった。

現在では, より厳密な管理を行ってめっきの品質 を安定化させるため, CVS をオンライン化した分析 システムが現場に適用されている。

\section{3.はんだ（錫一鉛合金）めつき}

はんだめっきは, 弱電部品や電子工業用部品をは じめ, プリント配線板のスルーホールめっきに用い られている。

プリント配線板のはんだめっきは, 光沢めっき浴 と無光沢めっき浴が用いられている。光沢めっき浴 は, はんだ需れ性やめっき外観が良いことなどから, 主としてフレキシブル板 (FPC) に用いられている。

リジッド板のはんだめっきは, エッチングレジス トとしての信頼性, フュージング性などが重要視さ れるため, 無光沢のホウフッ化浴が主流となってい る。プリント配線板のはんだめっきに要求される めっき性能は, 次の通りである。

(1) スローイングパワーが優れている

(2) ピンホールがなく，滑らかで緻密である

（3）錫一鉛の析出比率が安定している

（4）有機共析物によるアウトギャッシングがない エッチングレジストとしてのはんだめっきは, テ ンティング (ドライフィルム) や穴埋め法（樹脂, インク）に比べ, 皮膜の硬さや取り扱いの容易性が 優れており，信頼性は最も高い。はんだめっきは, フュージングを考慮して, 錫 $60 \%$-鉛 $40 \%$ の析出比 率で, 膜厚 $7 \sim 10 \mu \mathrm{m}$ のっきが多く使用されている。

表 3 に光沢はんだめっきと無光沢はんだめっきの 浴組成とめっき条件を示した。はんだめっきは, 錫 $(-0.130 \mathrm{~V})$ と鉛 $(-0.126 \mathrm{~V})$ とは析出電位が接近し ており, 平衡共析（析出した合金中の 2 金属の比が 溶液中の金属濃度比と同じ）であるので容易に一定 の比率で共析しやすい。

表 3 . 光沢はんだめっきと無光沢はんだめっきの浴組成

\begin{tabular}{l|c|c}
\hline & 光沢はんだめっき & 無光沢はんだめっき \\
\hline $\mathrm{Sn}$ & $30 \mathrm{~g} / \ell$ & $16 \mathrm{~g} / \ell$ \\
\hline $\mathrm{Pb}$ & $18 \mathrm{~g} / \ell$ & $11 \mathrm{~g} / \ell$ \\
\hline ホウフッ化水素酸 & $240 \mathrm{~g} / \ell$ & $110 \mathrm{~g} / \ell$ \\
\hline 光沢剤 & $40 \mathrm{~m} \ell / \ell$ & \\
\hline 分散剤 & $60 \mathrm{~m} \ell / \ell$ & \\
\hline ホルマリン & $10 \mathrm{~m} \ell / \ell$ & \\
\hline 添加剤 & & \\
\hline 酸化防止剤 & & 若干 \\
\hline
\end{tabular}


最近では，ホウフッ化浴の公害対策としてノン フッ化浴の採用が増加している。ノンフッ化浴は, 数年前まではスローイングパワーや析出比率に問題 があったが, 現在では添加剤の改良が進み, ホウフッ 化浴とほ沽同程度の性能が得られるようになった。

\section{1 スローイングパワー（均一電着性）}

はんだめっきは, エッチングレジストとしてス ルーホール内の銅めっき皮膜を確実に保護する必要 がある。そのため,はんだめっきのスローイングパ ワーは, 重要な性能の 1 つとなっている。

図 1 にホウフッ化浴とノンフッ化浴のスローイン グパワーの比較を示した。図1 から明らかなように, ノンフッ化浴の方がホウフッ化浴に比べてスローイ ングパワーが良好であることがわかる。

\section{2 析出比率}

はんだめっき浴の析出比率を調べる方法は, 測定 值の信頼性, 迅速性などから蛍光 $\mathrm{X}$ 線微小部膜厚計 が使用されている。例えば，ハルセルテスト後のパ ネルの電流密度と析出比率の関係を調べることによ り，最適な浴管理を行うことができる。図 2 にハル セルパネルによるホウフッ化浴とノンフッ化浴の電 流密度と析出比率の関係を示した。

析出比率は, 次の要因により影響を受ける。

(1) 浴組成

(2) 電流密度

（3）添加剤の種類と濃度

（4）陽極の合金比率

（5）めつき浴の污染度

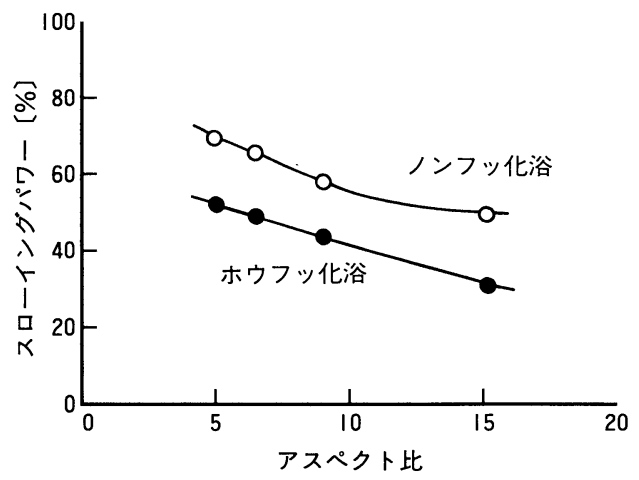

図1 、ホウフッ化浴とノンフッ化浴のスローイング パワー比較

（板厚 $4.6 \mathrm{~mm}$, 電流密度 $1 \mathrm{~A} / \mathrm{dm}^{2}$ )

\section{3 浴污染の影響}

はんだめっき浴の污染には，有機物と不純金属に よる污染がある。有機污染は, 添加剤の分解生成物 の蓄積やめっきレジスト成分の溶出, 前処理工程か らの脱脂剤成分等の持ち込みによるものである。は んだめっき浴中に有機污染物の蓄積量が増加する と, リフロー時にアウトギャッシングのトラブルを 引き起こしたり，析出比率を悪化させてしまう。そ のため, 有機污染物の蓄積を抑えるために, 定期的 な活性炭処理が行われている。

最近では，水溶性レジストの普及とともに，めつ きレジスト成分の溶出の問題がクローズアップされ ている。その理由として, レジストの解像度を向上 させるための添加剤成分 (増感剂等)が，はんだめつ き液に溶出し，污染するためである。レジスト成分 の溶出物は，析出比率に悪影響を与元，皮膜の特性 を悪化させる場合がある。図 3 に A 社ドライフィル ムをめっき液に浸せきしたときの析出比率の変化を 一例として示した。

不純金属の污染源は，硫酸銅めっきからの持ち込 み，陽極ブスバーおよび陽極フックの溶解，治具か らの溶出等が考えられる。めっき液から検出される 不純金属は，銅，鉄，ニッケル，クロムなどである。 この中で，特に悪影響の大きい金属は銅であり，析 出粒子をあらし，析出比率に大きな変化を与える。

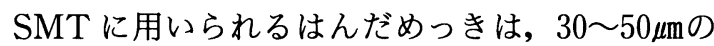
厚い皮膜を高純度に，安定した析出比率で析出させ る必要があり，めっき液の管理およびめっき条件な

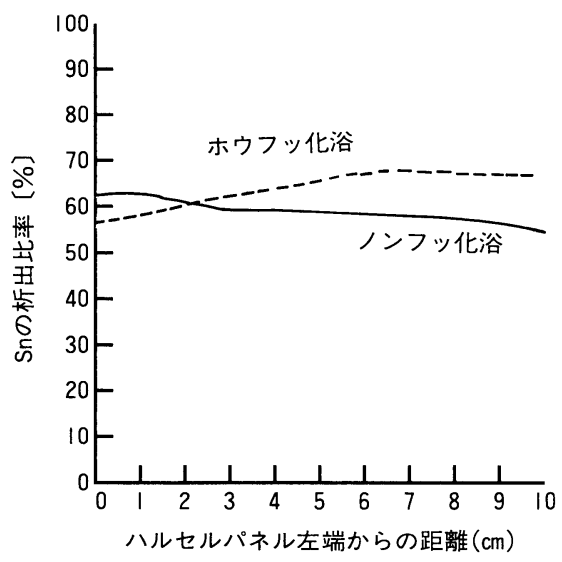

図 2 . ホウフッ化浴とノンフッ化浴の析出比率の比較 


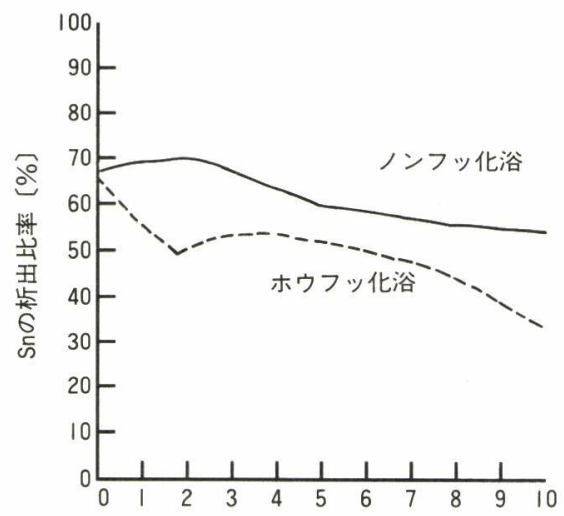

ハルセルパネル左端からの距離 $(\mathrm{cm})$

図 3 . ホウフッ化浴とノンフッ化浴のレジスト污染の 影響

どに厳密さが要求されている。特に，めつき液に使 用される薬剤や陽極の純度チェックは必ず必要とな る。めっき液中に蓄積した不純金属の除去には, 定 期的な低電流密度での空電解が効果的である。

\section{4、あとがき}

硫酸銅めつきは，基板の高密度，高多層化に伴っ て, めっき皮膜の性能, 管理方法等により厳密さが 要求されてきている。それらの要求に対応するため, より優れためっき添加剤の開発や添加剤の分析管理 技術の確立が必要と思われる。

はんだめっきは, 水溶性レジスト成分の溶出の問
題に対応するため，有機污染に対し許容範囲の広い めっき液の開発，めっき液中のレジスト成分の分析 法の確立が急務と思われる。

また，プリント配線板の製造に使用する電気めつ きには，環境問題，人体への影響などを考慮し，安 全なめっき薬品を選定していくべきであると思われ る。 (1993.3.22-受理)

\section{文献}

1) J. Darken: "Electroless copper an alternative to formaldehyde", Printed Circuit World Convention V, pp.12-15 (1990)

2 ) 公開特許 平2-305971

3 ) 豊永 実：“プリント配線板のめつき技術の動 向”，めっき技術交流会テキスト，p.39 (1991)

4 ) G.L. Fisher : "Electroplating of High Aspect Ratio Holes”, PC Fab., Vol. I2, No.4, p.39 (1989)

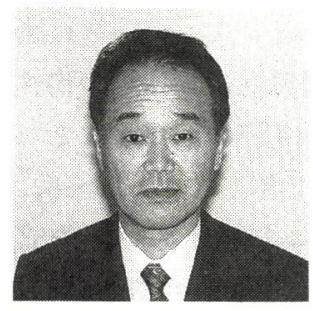

\section{千葉 国雄}

昭和 16 年生まれ。昭和 39 年東海大 学工学部金属工学科卒業。現在, メルテックス株式会社研究部にお いて, 表面処理薬品の開発に従事。 